\title{
Прививка томата (Solanum licopersicum L.) на картофель (Solanum tuberosum L.)
}

Партоев К., д.с.-х.н., профессор

Институт ботаники, физиологии и генетики растений АН Республики Таджикистан, Таджикистан, г. Душанбе.

e-mail:pkurbonali@mail.ru

Опыт по проведению прививки томата на картофель осуществлен на экспериментальном участке Института ботаники, физиологии и генетики растений Академии наук Республики Таджикистан на высоте 840 м над уровнем моря. Исходным материалом для опыта служили растения картофеля сорта Paшт (Solanum tuberosum L.), у которого клубни имеют красную окраску и томаты сорта Волгоградский-5/95 (Solanum licopersicum L.). Растения картофеля и томата вместе были посажены в железный сосуд, заполненный почвой и перепревшим навозом (соотношение 3:1). Для проведения прививки стебля растений повреждали на высоте 10 см от почвы при помощи лезвия в длину 8-10 см и поврежденные части стеблей двух растений соединили друг с другом и замотали тонкой пленкой. После 15 дней, когда образовался каллус, лезвием вырезали ниже от места прививки стебель растений томата, то есть отделяли стебель томата от корней, а сверху от места прививки срезали стебель растения картофеля. Было образовано растение, состоящее из картофеля и томата. Установлено об изменение качественного признака-окраски клубней картофеля под воздействием донора - растений томата.

Ключевые слова: картофель, томаты, прививка, окраска клубней, Таджикистан.

\section{Grafting of tomato (Solanum licopersicum L.) on potatoes (Solanum tuberosum L.)}

Partoev Kurbonali, Institute of Botany, Plants Physiology and Genetics of AS of the Republic of Tajikistan; 734017, Tajikistan, Dushanbe, Karamov St., 27. Email:pkurbonali@mail.ru

Experiment on carrying out an grafting of tomato on potatoes is carried out on the experimental site of Institute of Botany, Plants Physiology and Genetics of Academy of Sciences of the Republic of Tajikistan at the height of $840 \mathrm{~m}$ above sea level. As initial material for experiences served grade potatoes plants Rasht (Solanum tuberosum L.), at which tubers have red coloring and tomatoes of a grade Volgograd-5/95 (Solanum licopersicum L.). Plants of potatoes and a tomato were together planted in the iron vessel filled with the soil and the retorting manure (a ratio 3:1).

For carrying out grafting of a plant of a tomato on potatoes the following 
method of an inoculation was used. Stalks of a plant of potatoes and a tomato damaged at the height of $10 \mathrm{~cm}$ from the soil by means of an edge in length of 8$10 \mathrm{~cm}$ and the damaged parts of stalks of two plants connected with each other and rolled up a thin film. After 15 days when it was formed callus, an edge cut out below from the place of an inoculation a stalk of plants of a tomato, that is separated a tomato stalk from roots, and from above from the place of an inoculation cut off potatoes plant stalk. In experience it is established about change of qualitative sign-colorings of tubers of potatoes under the influence of the donor - tomato plants.

Key words: potato, tomato, grafting, coloring of tubers, Tajikistan.

Прививка - один из способов вегетативного размножения плодовых растений, и она основана на изменении характера питания - обмена веществ между двумя или несколькими прививаемыми формами [5]. Проведенные эксперименты на основе прививки двух сортов табака и анализа РНК и ДНК клетки установлено, что каждая из этих клеток действительно содержит все четыре гена, и все они работают (транскрибируются, то есть используются в качестве матрицы для синтеза РНК) $[5,6]$. Анализ пластидных и ядерных генетических маркеров показал, что в генетическом обмене участвовала только пластидная, но не ядерная ДНК. Из клеточных культур, содержащих смешанный генетический материал двух сортов табака, удалось вырастить взрослые растения, способные к половому размножению. Из их семян выросли растения с теми же признаками, что и у гибридных родителей. Это означало, что новая комбинация признаков, полученная в результате генетического обмена между клетками привоя и подвоя, действительно может стать наследственной, а, следовательно, «вегетативная гибридизация» всетаки возможна, по крайней мере в лабораторных условиях $[5,6]$. В настоящее время горизонтальному переносу генов (ГПГ) уделяется все больше внимания, как процессу, имеющему биологическое значение в формировании эволюционной истории с начала жизни на Земле $[1,2,4]$. По сообщениям [3] еще в 1978 году в Генетическом институте в Германии был получен межродовой гибрид - помитофель, и о результатах на Генетическом конгрессе в Москве докладывали по соматической гибридизации отдаленных видов. Был показан гибрид помитофель - с миниклубнями - в «корешках» и маленькими помидорами - в «вершках». В результате слияния протопластов томата и картофеля был получен гибрид (помитофель), но он был далек от идеала. Однако растения с неулучшенным фотосинтезом не могут работать на «два фронта» и для формирования полноценного урожая томатов и клубней гибрида необходимо удвоить активность фотосинтетического аппарата [3]. Для изучения этого процесса нами были проведены этих полевых опытов. Опыт по проведению прививки томата на картофель был проведен в июне 2019 года на опытном участке Института ботаники, физиологии и ге- 
нетики растений Академии наук Республики Таджикистан. Исходным материалом для опытов служили растения картофеля сорта Рашт (Solanum tuberosum L.), у которого клубни имеют красную окраску и томаты сорта Волгоградский-5/95 (Solanum licopersicum L.). Растения картофеля и томата вместе были посажены в железный сосуд, заполненный почвой и перепревшим навозом (соотношение 3:1). Для проведения прививки растения томата на картофель был использован следующий метод прививки. Стебли растения картофеля и томата повреждали на высоте 10 см от почвы при помощи лезвия в длину 8-10 см и поврежденные части стеблей двух растений соединили друг с другом и замотали тонкой пленкой. После 15 дней, когда образовался каллус, лезвием вырезали ниже от места прививки стебель растений томата, то есть отделяли стебель томата от корней, а сверху от места прививки срезали стебель растения картофеля.

Таким образом, подвоем служило растение картофеля, а привоем томаты и было образовано растение, состоящее из картофеля и томата. В течение вегетации прививших растений картофеля и томата подкармливали аммиачной селитрой из расчета приблизительно 2 г на сосуд и систематический поливали.

В конце вегетации из привоя (томаты) нами были собраны четыре штуки созревших плодов томата (весом всего 100 г), а также из подвоя (картофеля) - три клубня картофеля (весом всего 120 г) (рисунок).
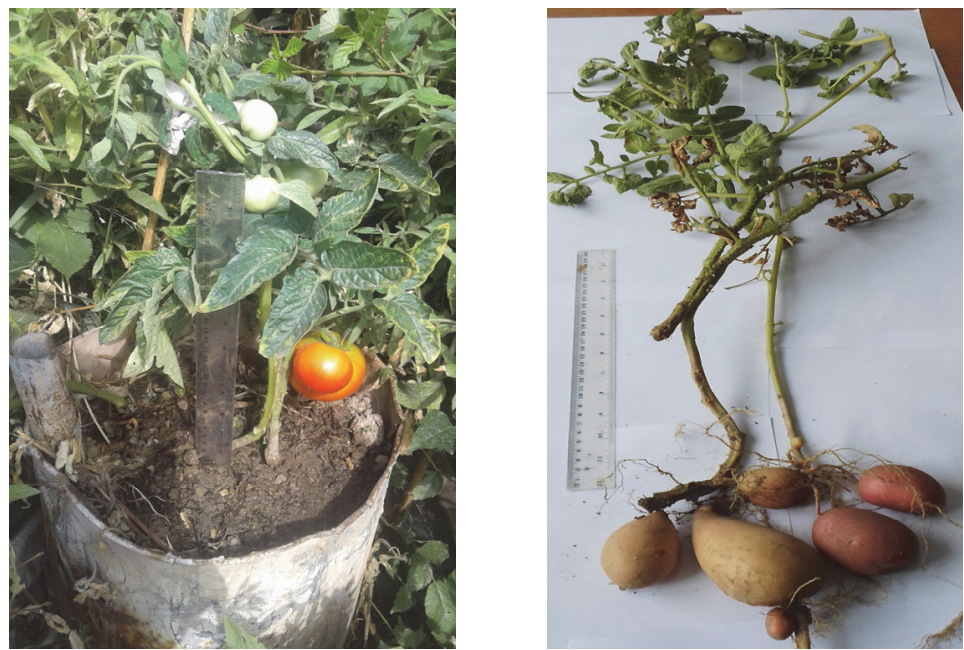

Рисунок. Привитые растения картофеля и томата в железном сосуде с плодами томата (слева) и клубнями картофеля, образовавшимися на привитом стебле картофеля с бледно-розовой окраской (справа - $\mathrm{C}_{1}-$ первая клоновая репродукция), а также красные клубни, сформировавшиеся от глазков клубня с бледно-розовой окраской ( $\mathrm{C}_{2}-$ вторая клоновая репродукция). 
Необходимо отметить, что под влиянием донора-привоя (растение томаты) клубни картофеля сорта Рашт, имеющие красную окраску, приобрели бледно-розовую $\left(\mathrm{C}_{1}\right)$, а вкус плодов томата также был более сладким, чем обычные (без прививки) плоды томата. Однако от клубня с бледно-розовой окраской, от вторичного зарастания проросло новое растение $\left(\mathrm{C}_{2}\right)$, и оно сформировало клубни с красной окраской, что видно на фото (справа).

Таким образом, в условиях Гиссарской долины Таджикистана, на экспериментальном участке Института ботаники, физиологии и генетики растений АН Республики Таджикистан, расположенном на высоте 840 м над уровнем моря, впервые осуществлена прививка картофеля и томата. В результате этого опыта получена необходимая научная информация об изменении качественного признака - окраски клубней картофеля под воздействием донора - растений томата. Однако генетическая и физиологическая природа этого явления пока не установлена. Необходимо отметить, что в предыдущих наших опытах при проведении прививки топинамбура на подсолнечник, картофеля на баклажаны, также нами было обнаружено изменение ряда качественных и количественных признаков растений подвоя и привоя, что необходимо в будущем проведение дальнейших экспериментов в этом направлении.

\section{Список литературь}

1. Марков А.В. Горизонтальный перенос генов и эволюция / А.В. Марков // http://evolbiol.ru/lgt2008/lgt2008.htm.

2. Матвеева Т.В. Роль горизонтального переноса генов в эволюции высших растений / Т.В. Матвеева // Международной конференции «125 лет прикладной ботаники в России». 2-28 ноября 2019 г. - Санкт-Петербург, Россия, 2019. - 160 с.

3. Насыров Ю.С. Факел познания. Москва / Ю.С. Насыров // «Колос», 1994. - 111 с.

4. Шестаков С.В. Роль горизонтального переноса генов в эволюции. / С.В. Шестаков // Горный Алтай, стационар "Денисова Пещера". Электронная публикация. http://evolbiol.ru/shestakov.htm

5. Rusk N. (2009) «Grafting as a potent molecular tool», Nature Methods 6, 484 http://www.nature.com/nmeth/journal/v6/n7/full/nmeth0709-484.html

6. Sandra Stegemann, Ralph Bock. Exchange of Genetic Material Between Cells in Plant Tissue Grafts // Science. 2009. V. 324. P. 649-651. 